\title{
The Time Has Come for an International Criminal Court
}

\author{
M. Cherif Bassiouni*
}

\section{Introduction}

The end of the "Cold War" presents an historic opportunity to advance the international rule of law by establishing an international criminal court to preserve peace, advance the protection of human rights and reduce international and transnational criminality.

The idea for such a court is not new and the efforts to establish it have increased over the years. All of the precedents, however, have been ad hoc international tribunals which ceased to exist when the specific function or purpose for which they were designed ended. But the important legal fact is that they existed, albeit with all the weaknesses and shortcomings of having been hastily established, created for a single adjudicating purpose and temporary in nature. Nevertheless, these precedents are the backdrop of international experience which must now ripen into a permanent international adjudicating structure designed to apply international criminal law with consistency and objectivity, and by means of fair process.

\section{Historical Background}

It can be said that the first international criminal court was established in 1474 in Breisach, Germany, where 27 judges of the Holy Roman Empire judged and condemned Peter von Hagenbach for his violations of the "laws of God and man" because he allowed his troops to rape and kill innocent civilians and pillage their property.' Since then, a number of similar precedents have taken place and moreover,

- Professor of Law, President, International Human Rights Law Institute, DePaul University; President, International Association of Penal Law; President, International Institute of Higher Studies in Criminal Sciences.

1. G. SchWarzenberger, International Law as Applied by International Courts and Tribunals 462 (1968). See also M.H. KeEn, The Laws of War in the Late Middle Agrs 23-59 (1965). 
a number of initiatives for a permanent international criminal court have been developed. (See Appendix I for the chronology of these initiatives.)

-After World War I, the Treaty of Versailles provided for the prosecution of Kaiser Wilhelm $\mathrm{II}^{2}$ and for an international tribunal to try German war criminals. ${ }^{3}$ After the war, the Kaiser fled to the Netherlands where he obtained refuge, but the Allies, who had no genuine interest in prosecuting him, abandoned the idea of an international court. ${ }^{4}$ Instead, they allowed the German Supreme Court sitting at Leipzig to prosecute a few German officers. ${ }^{5}$ The Germans criticized the proceedings because they were only directed against them and did not apply to Allied personnel who also committed war crimes. More troublesome, however, was the Allies' failure to pursue the killing of a then estimated 600,000 Armenians in Turkey. 6 The 1919 Commission on the Responsibilities of the Authors of the War and on the Enforcement of Penalties for Violations of the Laws and Customs of War, which investigated the responsibility of those who violated the laws of war, recommended the prosecution of responsible Turkish officials and by doing so, the notion of "crimes against humanity" became a legal reality. ${ }^{7}$ Strange as it may seem today, the United States, at that time, opposed such prosecution on the technical legal argument that no such crime yet existed under positive international law. ${ }^{8}$ Consequently, the Treaty of Sèvres (1923), which was to serve as a basis for Turkish prosecutions, was never ratified, ${ }^{9}$ and its replacement, the Treaty of

2. Treaty of Peace Between the Allied and Associated Powers and Germany (Treaty of Versailles), 28 June 1919, 11 Martens Nouveau Recueil des Traites (3d) 323, art. 227.

3. Id., art. 228.

4. See genetally J.F. Willis, Prolocue to Nurembero (1982); see also, Wright, The Legality of the Kaiser, 18 AM. Por. Sci. Rev. 121 (1919).

5. See C. Mullins, The Leipzic Trials (1921). The two major prosecutions were "The Dover Castle," (reprinted in 16 AM. J. INT'L L. 704 (1922)), and "The Llandovery Castle," (reprinted in 16 AM. J. INT'L L. 708 (1922)).

6. See generally Dadrian, Genocide as a Problem of National and International Law: The World War I Amenian Case and its Contemporary Legal Ramifications, 14 YALE J. INT'L L. 221 (1989).

7. Report of the Commission on the Responsibilities of the Authors of the War and on Enforcement of Penalties for Violations of the Laws and Customs of War, Conference of Paris 1919, Carnegie Endowment for International Peace, Division of International Law, Pamphlet No. 32 (1919), reprinted in 14 AM. J. INT'L L. 95 (Supp. 1920).

8. Id., Dissent of the United States, at 58 (of Pamphlet No. 32).

9. The Treaty of Peace Between the Allied Powers and Turkey (Treaty of 
Lausanne (1927), gave the Turks amnesty. ${ }^{10}$ Thus, the first of many mass killings in this century - atrocities now commonly referred to as genocide" - remained unpunished. Nevertheless, one can assume that the granting of amnesty constituted implicit legal blameworthiness; i.e., amnesty is only granted for a crime. The reluctance to recognize

Sèvres), 10 August 1920, 15 Am. J. INT'L L. 179 (Supp. 1921) (not ratified). See in particular arts. 226-230. Article 226 provides:

The Turkish Government recognises the right of the Allied Powers to bring before military tribunals persons accused of having committed acts in violation of the laws and customs of war. Such persons shall, if found guilty, be sentenced to punishments laid down by law. This provision will apply notwithstanding any proceedings or prosecution before a tribunal in Turkey or in the territory of her alies.

The Turkish Government shall hand over to the Allied Powers or to such one of them as shall so request all persons accused of having committed an act in violation of the laws and customs of war, who are specified either by name or by the rank, office or employment which they held under the Turkish authorities.

See generally Matas, Prosecuting Crimes Against Humanity: The Lessons of World War I, 13 FORD. INT'L L. J. 86 (1989).

10. In fact, the treaty did not even address the question of prosecuting war criminals. Treaty of Peace between the Allied Powers and Turkey (Treaty of Lausanne), 24 July 1923, 28 L.N.T.S. 11, reprinled in 18 AM. J. INT't L. 1 (Supp. 1924). See generally, Garner, Punishment of Offenders Against the Laws and Customs of War, 14 AM. J. INT'L L. 70 (1920).

11. See Convention on the Prevention and Suppression of the Crime of Genocide, 9 Dec. 1948, 78 U.N.T.S. 277, reprinted in 45 AM. J. INT'L L. 7 (Supp. 1951). Article II defines genocide as follows:

In the present Convention, genocide means any of the following acts committed with intent to destroy, in whole or in part, a national, ethnical, racial, or religious group, as such:

(a) Killing members of the group;

(b) Causing serious bodily or mental harm to members of the group;

(c) Deliberately inflicting on the group conditions of life calculated to bring about its physical destruction in whole or in part;

(d) Imposing measures intended to prevent births within the group;

(e) Forcibly transferring children of the group to another group.

On its face, this definition excludes mass killings which are committed without the accompanying intent to destroy a group "in whole or in part." See Bassiouni, Introduction to the Genocide Convention, in 1 M.C. Bassiouni, International Criminal Law: Crimes 281 (1986). See also, E. Aroneau, le Grime Contre L'Humanite (1961); P. Drost, The Crime of State (1959); Bassiouni, Intemational Law and the Holocaust, 9 Cat. W.J. INT'L L. 201, 250 (1979); Lemkin, Genocide as a Crime Under Intemational Law, 41 Am. J. INT'z L. 145 (1944). 
"crimes against the laws of humanity" in the post-World War I era as prosecutable and punishable international crimes came back to haunt the very same Allies, and particularly the United States, after World War II.

-In 1937, the League of Nations adopted a Convention Against Terrorism. The Protocol to this Convention contained a Statute for an International Criminal Tribunal; however, India was the only country to ratify it and the Convention never entered into effect. ${ }^{12}$ Since then, the world has been plagued with all sorts of terror-violence, producing significant victimization, and as a consequence, a number of international Gonventions on the subject have been adopted but none contained a provision for the establishment of an international criminal court as did the 1937 Convention. ${ }^{13}$ Once again the short-sightedness of public officials prevented the taking of that additional step which many felt to be necessary. ${ }^{14}$

-After World War II, the Allies established two international tribunals - at Nuremberg ${ }^{15}$ and Tokyo ${ }^{16}$ - to try major war criminals; however,

12. Convention for the Creation of an International Criminal Court. Opened for signature at Geneva, Nov. 16, 1937, League of Nations O.J. Spec. in Supp. No. 156 (1938), League of Nations Doc. G.547(I).M.384(I).1937V. (Never entered into force); reprinted in 7 International Legislation (1935-37), 878 (M. Hudson ed. 1972).

13. See Convention for the Suppression of Unlawful Seizure of Aircraft, 16 Dec. 1970, 860 U.N.T.S. 105; Convention for the Suppression of Unlawful Acts Against the Safety of Civil Aviation, 23 Sept. 1971, 974 U.N.T.S. 177; Convention on the Prevention and Punishment of Crimes Against Internationally Protected Persons, Including Diplomatic Agents, 14 Dec. 1973, T.I.A.S. No. 8532; International Convention Against the Taking of Hostages, 18 Dec. 1979, G.A. Res. 34/145 (XXXIV), 34 U.N. GAOR Supp. (No. 46), at 245, U.N. Doc. A/34/146; Protocol for the Suppression of Unlawful Acts of Violence at Airports Serving Civil Aviation, 24 Feb. 1988, 27 I.L.M. 627 (1988); Convention and Protocol from the International Conference on the Suppression of Unlawful Acts Against the Safety of Maritime Navigation, 10 Mar. 1988, I.M.O. Doc. SVA/GON/15.

14. See International Terrorism and Political Grimes, (M.C. Bassiouni ed. 1975). In particular, see "Final Document: Conclusions and Recommendations" (of the participants to the International Conference on Terrorism and Political Crimes, held at the International Institute of Higher Studies in Criminal Sciences, June 4-16, 1973), at xi-xxii.

15. Agreement for the Prosecution and Punishment of Major War Criminals of the European Axis (London Agreement), 8 Aug. 1945, 82 U.N.T.S. 279, 59 Stat. 1544, E.A.S. No. 472 (entered into force, 8 Aug. 1945), and the annexed Charter of the International Military Tribunal (Nuremberg). See generally, TriaI of the Major War Criminals: Procegdings Before the International Military Tribunal (1949), known as the "Blue Series." The ensuing trials were published under the title, TrLals of War Criminals Before the Nuremberg Military Tribunal (1949), known as the 
the absence of a strong precedent in the post-World War I era weakened the legality of the process. Even worse was the absence of prosecution of Allied military personnel for war crimes. These and subsequent prosecutions became tainted with the claim of "victor's vengeance," although the legitimacy of prosecuting such offenders by far outweighed the legal weaknesses of the process and certainly outweighed nonprosecution. Subsequent to Nuremberg and Tokyo, the Allies established war crimes tribunals in their respective zones of occupation in Germany and tried over 20,000 war criminals. ${ }^{17}$ Germany then took over the task of prosecuting offenders found in its territory. ${ }^{18}$ Formerly occupied countries of Europe also prosecuted Germans and their own nationals who collaborated with the occupiers. In some countries, the process continues. Suffice it to recall: Israel's Nazi and Nazi Collaborators (Punishment) Law, ${ }^{19}$ under which there were two landmark

"Green Series." For an account of the trial and the accused, see E. Davidson, THE TrIal of The Germans (1966). For a legal appraisal and description of the proceedings, see R. Woetzel, The Nuremberg Trials in International Law (1960); J. Keenan \& B. Brown, Crimes Against International Law (1950); S. Gluzck, War Criminals, Their Prosecution and Punishment (1944).

16. International Military Tribunal for the Far East: (a) Special Proclamation: Establishment of an International Military Tribunal for the Far East; (b) The Charter of the International Military Tribunal for the Far East, Tokyo, 19 Jan. 1946 (General Order No. 1), as amended 26 Apr. 1946, T.I.A.S. No. 1589, reprinted in 4 TREaties and Other International Agreements of the U.S.A., 1776-1949 20 (C.I. Bevans ed. 1968).

17. "Control Council Law No. 10" (Punishment of Persons Guilty of War Crimes, Crimes Against Peace and Against Humanity), adopted at Berlin, 20 Dec. 1945, Officlal Gazetre of the Control Council for Germany, No. 3, Berlin, 31 Jan. 1946, reprinted in 1 B. Ferencz, An International Criminal Court 488 (1980). See A. Maunoir, La Repression Des Crimes De Guerre Devant Les Tribunaux Francais et Allies (1956); History of the United Nations War Crimes Commission (Wright ed. 1948); Bierzanek, War Crimes: History and Definition, in 1 A Treatise oN International Criminal Law 559 (M.C. Bassiouni and V.P. Nanda eds. 1973); Cowles, Trial of War Criminals (non-Nuremberg), 42 AM. J. INT'L L. 299 (1948). In the post-Nuremberg prosecutions conducted in the occupied zones, the U.S. prosecuted 1814 persons (450 executed); the U.K. 1085 (240 executed); France, 2107 (109 executed). See Bierzanek, War Crimes: History and Definition, in 3 M.C. Bassiouni, InterNational Criminal Law: Enforcement, (1987). The U.S.S.R. is estimated to have prosecuted over 10,000 persons in Germany. No information is available on the number of persons executed. The United Nations War Crimes Commission also reported a number of other prosecutions in and throughout the European countries at war with Germany in World War II.

18. See Weinschenck, Nazis Before German Courts: The West German War Crimes Trials, 10 Int'L LaW. 515 (1976).

19. Nazi and Nazi Collaborators (Punishment) Law-5710 (1950) 4 LAws of 
prosecutions, Eichmann ${ }^{20}$ (convicted in 1961) and Demjanjuk ${ }^{21}$ (convicted in 1989); in Yugoslavia where Artukovic - extradited in 1988 from the United States - was executed in $1989 ;^{22}$ in France, where Barbie was convicted for the second time in $1989 ;{ }^{23}$ in the United States denaturalization and deportation of World War II criminals continues; ${ }^{24}$ and in Canada, where a 1987 law permits prosecution of persons charged with war crimes and crimes against humanity; $;^{25}$ the first case was decided in $1989 .{ }^{26}$ Prosecution of similar violations as those occurring after World War II has not taken place on any sort of consistent basis, notwithstanding many reported cases in regional conflicts and other conflicts of a non-international character. ${ }^{27}$ For

the State of Israel No. 64, at 154. See U.N. Yearbook on Human Rights 163 (1950) for the English translation of that law.

20. Attorney General of Israel v. Eichmann (Israel Dist. Court of Israel 1962), 36 I.L.R. 277 (1962). See genetally G. Hauser, Justice in Jerusalem (1966).

21. Extradited from the U.S. to Israel, In re Extradition of Demjanjuk, 612 F. Supp. 544 (N.D. Oh. 1985), aff'd, Demjanjuk v. Petrovsky, 776 F.2d 571 (6th Cir. 1985), cert. denied 475 U.S. 1016 (1986).

22. Artukovic v. Rison, 628 F. Supp. 1370 (C.D. Calif. 1986), aff'd, 784 F.2d 1354 (9th Cir. 1986).

23. See Matter of Barbie, Gaz. Pal. Jur. 710 (France Cass. crim. Oct. 6, 1983). See also Le Guhehec, "Affaire Barbie" Gazetle du Palais, No. 127-128, 106e anneé, Mercredi 7-Jeudi $8 \mathrm{Mai}, 1985$; and Angevin, "Enseignements de L'Affaire Barbie en Matiere de Crimes Contre l'Humanité," La Semaine Juridique, 62e anneé, No. 5, 14 Dec. 1988 p. 2149; Doman, Aftermath of Nuremberg: The Trial of Klaus Barbie, 60 Cono. L. REv. 449 (1989).

24. On the revocation of naturalization, see 8 U.S.C. $\$ 1451$ (1988). See also Alleged Nazi War Criminals: Hearings Before the Subcommittee on Immigration, Citizenship and International Law of the House Committee on the Judiciary, 95th Cong., 1st Sess. 59 (1977). And see generally, A. Ryan, Quiet Neighbors: Prosecuting Nazi War Criminals in America (1984) (examining the issue of war criminals who emigrated to the United States and who now must confront their past).

25. See Act to amend the Criminal Code, ch. 37, 1987 Can. Stat. 1107. (See in particular 1.96.). Also, Australia and the United Kingdom have passed or considered similar legislation. In Australia: War Crimes Act 1988, No. 3 of 1989, 25 Jan. 1989; In the U.K. see WAR Crimes: Report of the War Crimes Inquiry (Presented to Parliament by the Secretary of State for Home Department by Command of Her Majesty, July 1989). 1990).

26. The Queen v. Imre Finta, Court File No. $30 / 88$ (Sup. Ct. of Ontario,

27. See generally Mudge, Starvation as a Means of Warfare, 4 INT'L LAw. 228 (19691970) [Biafra; Nigeria]; Kampuchea: Decade of the Genocide (K. Kiljunen ed. 1984); Frank \& Rodley, After Bangladesh: The Law of Humanitarian Intervention by Military Force, 67 Am. J. INT'L L. 275 (1973); and Commentary, International Crimes Tribunal in Bangladesh, 11 Inr'l Comm. JuR. Rev. 29 (N. MacDermot ed. 1973); Paust \& 
example, only one conviction arose out of the Vietnam War. ${ }^{28}$ -In 1948, the Genocide Convention recognized the jurisdiction of an international criminal court, should one be established, but the Convention.did not require that such a court be established. ${ }^{29}$ Since 1948, however, mass killings have gone unpunished, including those resulting from the internal conflicts in Biafra (Nigeria), Bangladesh and Kampuchea, where the killing is still ongoing. ${ }^{30}$

-As a result of the post-World War II prosecutions, the United Nations established a Committee for the codification of "Offences Against the Peace and Security of Mankind" 31 and also to develop the statute for an international criminal court. In 1951, such a draft statute was prepared $^{32}$ and in 1953 , it was amended,,$^{33}$ but it has been tabled by

Blaustein, War Crimes Jurisdiclion and Due Process: The Bangladesh Experience, 11 VAND J. Trans. L. 1 (1978); The Asia Watch Committee, Khmer Rouge Abuses Along the Thai-Cambodian Border (1989). See also L. Kuper, Genocide (1981).

28. U.S. v. Calley, 46 C.M.R. 1131 (1973), aff'd 48 C.M.R. 19 (1973); see also 2 L. Friedman, The Law of War: A Documentary History 1703 (1972). .

29. Convention on the Prevention and Punishment of the Crime of Genocide, supra note 11, art. IV.

30. See supra note 27.

31. See generally Williams, The Draft Code Against the Peace and Security of Mankind, in 1 M.C. Bassiouni, International Criminal Law: Crimes 109 (1986).

32. Draft Statute for an International Criminal Court (Annex to the Report of the Committee on International Criminal Court Jurisdiction, 31 Aug. 1951), 7 U.N. GAOR Supp. (No. 11), U.N. Doc. A/2136 (1952), at 23. See also subsequent Reports of the Committee on International Criminal Jurisdiction, U.N. Doc. A/2186 and U.N. Doc. A/2186/Add. 1. The discussions of the Sixth Committee and of the General Assembly until the end of 1952 encompassed all three reports (U.N. Doc. A 2136, U.N. Doc. A/2186, U.N. Doc. 2186/Add.1). See also Historical Survey of the Question of International Criminal Jurisdiction, Memorandum by the Secretary-General, A/CN.4/7/Rev.1 (1949), reprinted in 1 B. Ferencz, An International, Criminal Court 399 (1980). The chronology of relevant U.N. documents, reports and resolutions are: Report of the International Law Commission on the Question of International Criminal Jurisdiction, U.N. Doc. A/CN.4/15 (1950); Report of the International Law Commission to the U.N. General Assembly on the Question of International Criminal Justice, 5 U.N. GAOR Supp. (No. 12), at 18, U.N. Doc. A/1316 (1950); Report of the Sixth Committee to the U.N. General Assembly concerning the Report of the International Law Commission on the Question of International Criminal Jurisdiction (U.N. Doc. A/1316), 5 U.N. GAOR, U.N. Doc. A/1639 (1950); Report on the International Griminal Jurisdiction, 7 U.N. GAOR Supp. (No. 11), U.N. Doc. A/ 2136 (1951) (Final).

33. Report of the 1953 Committee on International Criminal Jurisdiction to the Sixth Committee, 9 U.N. GAOR Supp. (No. 12), at 23, U.N. Doc. A/2645 (1953); Report of the Sixth Committee to the U.N. General Assembly considering the (Final) Report of the 1953 Committee on International Criminal Jurisdiction (U.N. 
the General Assembly ever since.

-In 1972, the Apartheid Convention provided for the establishment of an international criminal jurisdiction. ${ }^{34}$ In 1980 , at the request of the Commission on Human Rights, I prepared a draft statute for an international criminal tribunal to prosecute apartheid violators, but the project thus far has not been acted upon. ${ }^{35}$

-In 1989 and 1990, the General Assembly requested the International Law Commission to report on the establishment of an international criminal court to prosecute persons engaged in the international trafficking of drugs. ${ }^{36}$ Pursuant to that call, the International Institute of Higher Studies in Criminal Sciences (Siracusa), in cooperation with the United Nations Crime Prevention Branch and the Italian Ministry

Doc. A/2645), 9 U.N. GAOR Supp., U.N. Doc. A/2827/Corr. 1 (1954); G.A. Res. 898 (X), U.N. Doc. A/RES./266 (1954) (tabling the Report of the 1953 Committee on International Criminal Jurisdiction); G.A. Res. 1187 (XII), 12 U.N. GAOR (1957) (tabling the Report of the Sixth Committee on International Criminal Jurisdiction, U.N. Doc. A/3771 (1957)).

34. International Convention on the Suppression and Punishment of the Crime of Apartheid, G.A. Res. 3068 (XXVIII), 28 U.N. GAOR Supp. (No. 30), at 75, U.N. Doc. A/9030 (1973), reprinted in 13 I.L.M. 50 (1974), arts. V, IX.

35. U.N. Doc. E/CN.4/AC.22/C.R.P. 19 (1980), "Study on ways and means of insuring the implementation of international instruments such as the International Convention on the Suppression and Punishment of the Crime of Apartheid, including the establishment of the international jurisdiction envisaged by the Convention," U.N. Doc. E/CN.4/1426, (1980). See also Bassiouni \& Derby, Final Report on the Establishment of an Intemational Criminal Court for the Implementation of the Apartheid Convention and Other Relevant Intemational Instruments, 9 Horstra L. REv. 523 (1981).

36. G.A. Res. 43/164 (1988) and 44/39 (1989). And, in particular, see Agenda item 152 entitled Intemational Criminal Responsibility of Individuals and Entities Engaged in Illicit Trafficking in Narcotic Drugs Across National Frontiers and Other Transnational Criminal Activities Establishment of an Intemational Criminal Court with Jurisdiction Over Such Crimes, Report of the Sixth Committee to the General Assembly, U.N. Doc. A/44/770 (1989). See also Adoption of a Political Declaration and a Global Programme of Action, Draft global programme of action by the Bureau of the Ad Hoc Committee of the Seventeenth Special Session of the General Assembly (Item 14 of the provisional agenda), U.N. Doc. VA/S-17/ AC.1/L.2 (1990), which at paragraph 80 provides:

Since the International Law Commission has been requested to consider the question of establishing an international criminal court or other international trial mechanism with jurisdiction over persons alleged to be engaged in illicit trafficking in narcotic drugs across national frontiers, the Administrative Committee on Co-ordination shall consider, in its annual adjustments to the United Nations system-wide action plan on drug abuse control requested by the General Assembly in its resolution 44/141 of 15 December 1989, the report of the International Law Commission on the question.

See generally, 84 AM. J. INT'L L. 930, 930-933 (1990). 
of Justice, convened a committee of experts in June 1990 to prepare such a draft statute. The Committee approved the document I prepared ${ }^{37}$

37. The Draft Statute for an International Criminal Court is based on the earlier proposal prepared by this author for the United Nations to prosecute apartheid violators. See supra note 35. Thereafter the Draft Statute was amended and published in M.C. Bassiouni, A Draft International Criminal Code and Draft Statute for an International Tribunal (1987). In preparation for the Siracusa meeting the Draft Statute was discussed at a meeting convened by Senator Arlen Specter:

But, the ILC is not the only forum for discussion of this proposal. Commencing later [sic] month in Italy, the International Institute of Higher Studies in Criminal Sciences in cooperation with the United Nations Crime Prevention Branch on Penal Codes will focus primary attention on the issue of creation of an international criminal court. And, in August, the United Nations' 8th Congress on Crime Prevention will also focus debate on the creation of such a court. Clearly, the progress made on the need for and creation of international criminal court has taken a quantum leap forward.

In sum, it is clear that there is broad agreement on the definition and threat posed by drugs and drug trafficking leading to the United Nations adoption on December 20, 1988 of the Convention against the Illicit Traffic in Narcotic Drugs and Psychotropic Substances. In spite of several international conventions on aviation, maritime safety and hostage-taking, there is less agreement on the definition of terrorism. While both represent a very serious problem to safety and security, the development of a regional international criminal court focusing on drugs and international drug trafficking, in my view, offers a start in establishing and developing the international criminal court system.

In closing, I wish to support the effort of the forthcoming fora in their efforts to create an international criminal court. In the months ahead I shall be introducing a new legislative proposal to move the United States closer to a more active role in the formulation of an international criminal court.

Mr. President, I would be gravely remiss if I did not recognize the extensive scholarship contributed by Cherif Bassiouni, professor of law at DePaul University College of Law to the development of an international criminal court and code. Professor Bassiouni's counsel and dedication have been a source of inspiration and guidance to this Senator and indeed to the community of international criminal lawyers and scholars. His competence and vision as an international criminal law scholar are universally shared. I thank him publicly for his contributions and leadership in this matter and look forward to greater cooperation with him in the formulative period ahead.

136 Conc. Rec. S8080 (daily ed. June 18, 1990) (statement of Sen. Specter). And also, after the Siracusa Conference:

[A] special committee of experts organized by the International Institute of Higher Studies in Criminal Sciences under the auspices of the Italian Ministry of Justice and in cooperation with the United Nations Crime Prevention and 
with minor changes and the text was submitted to the Eighth United Nations Congress on Crime Prevention and the Treatment of Offenders held in Havana, Cuba, August-September, 1990. ${ }^{38}$

-The Eighth Congress debated the subject and that discussion was summarized in its report as follows:

There was a need to develop clear ideas and a firm attitude on international co-operation, free of isolationism while respecting the sovereignty of States. Some delegations considered that the threat of major international crimes necessitated the establishment of an international criminal court. It would serve as an instrument for the defence of international peace and security, without which the sovereignty of some States, particularly small States, could be placed in jeopardy. ${ }^{39}$

The Congress, however, resolved as follows:

The International Law Commission should be encouraged to continue to explore the possibility of establishing an international criminal court or some other international mechanism to have jurisdiction over persons who have committed offences (including offences connected with terrorism or with illicit trafficking in narcotic drugs or psychotropic substances), in accordance with General Assembly resolution 44/39 of 4 December 1989. Similarly, and in the light of the report that the International Law Commission will submit on this particular subject to the General Assembly at its forty-fifth session, the possibility might be considered of establishing an international criminal court or appropriate mechanism with each and all of the procedural and substantive arrangements that might guarantee both its effective operation and absolute respect for the sovereignty and the territorial and political integrity of States and the self-determination of peoples. States

Criminal Justice Branch held a symposium in Siracusa, Italy. The Institute urged establishment of the court, drafted a model statute for such a court and presented its recommendations to the Eighth United Nations Congress on the Prevention of Crime and the Treatment of Offenders which met in August.

136 Conc. Rec. S18160 (daily ed. Oct. 25, 1990) (statement of Sen. Specter).

38. U.N. Doc. A/Conf. 144/NGO 7, Draft Statute: Intemational Criminal Tribunal (1990), Item 5, reprinted in 15 Nova L. Rev. 375 (1991). See also Bassiouni, A Comprehensive Strategic Approach on International Cooperation for the Prevention, Control and Suppression of International and Transnational Criminality, Including the Establishment of an International Criminal Court, 15 Nova L. Rev. 353 (1991).

39. Report of the Eighth United Nations Congress on the Prevention of Crime and the Treatment of Offenders, U.N. Doc. A/Conf. 144/28, at 227, (1990). 
could also explore the possibility of establishing separate international criminal courts of regional or sub-regional jurisdiction in which grave international crimes, and particularly terrorism, could be brought to trial and the incorporation of such courts within the United Nations system. ${ }^{40}$

-In July 1990, the International Law Commission completed a report and submitted it to the 1990 session of the General Assembly. ${ }^{41}$ It expressed a positive view on the feasibility of such a court with jurisdiction over "Crimes Against the Peace and Security of Mankind."

All these efforts have brought us closer to realizing the expectations of so many who believe that some form of international adjudication for international and transnational crimes may be forthcoming. But so far the political will of the world's major powers has been lacking, and progress toward that goal is slow though growing.

\section{Political, Practical and Technical Legal Considerations}

The obstacles to the establishment of an international criminal court fall essentially into three categories: (1) political; (2) practical; and, (3) legal-technical. Of these three, the political factor is the most significant, followed by the practical one, while the legal-technical one does not pose any serious difficulties.

The political factor stems essentially from objections generated by those who adhere to a rigid conception of sovereignty, even though such conceptions have been dépassé in so many other areas of international law, particularly with respect to the international and regional protections of human rights embodied in conventional and customary international law. The real opposition, however, comes from government officials who fear two types of situations.

The first is the risk that they and other senior officials, especially heads of state, can be called to answer for their acts which may constitute international violations and which would be subject to the Court's jurisdiction. This is not surprising in view of the fact that the Nuremberg ${ }^{43}$ and Tokyo"t international military tribunals, and the United Nations'

40. Id., at 193-4.

41. See supra note 36 , and accompanying text.

42. International Law Commission, Forty Second Session, U.N. Doc. A/CN.4/ 430/Add.1 (1990) Eighth Report on the Draft Code of Crimes Against the Peace and Security of Mankind.

43. See subra note 15.

44. See supra note 16. 
subsequent affirmation of the Nuremberg principles, removed the immunity of heads of states and negated other defenses, such as "obedience to superior orders." "45

Since World War II a number of instances have come to world public attention indicating that heads of state and senior government officials have engaged in or supported the commission of such international crimes as aggression, war crimes, crimes against humanity, genocide, apartheid, slavery and slave-related practices, international trafficking in drugs, aircraft hijacking, kidnapping of diplomats, taking of civilian hostages and torture. And while the world community expresses abhorrence of some of these crimes, and outrage about others, little if anything is done, other than pious denunciations, and occasionally, some condemnatory resolutions by the United Nations and other international bodies.

The political problem is obvious. Heads of states and senior government officials have historically wanted to shield themselves from any form of international accountability. Their successors and even their opponents so frequently cover up for them for fear that they too may find themselves in a similar situation, or because they feel that domestic political peace may warrant it. This was evident when Bangladesh did not carry out its intended prosecution of Pakistanian military personnel after the independence of that region, which was once part of Pakistan. ${ }^{46}$ It was also the case when Argentina, after prosecuting some officers for the estimated 15,000 desaparecidos between 1976-1983, passed an amnesty law on December 29, 1990.47

During the "cold war" (1948-1989) countries on both sides of the then "iron curtain" perceived the exigencies of national security at precluding consideration of an international criminal court that would deal with such international crimes as aggression and terrorism. But the real reason was that the two superpowers engaged in acts violating international criminal law, as did their surrogates, satellites and respective friendly countries. Exaggerated as these claims of national

45. See Affimation of the Principles of Intemational Law Recognized by the Charter of Nuremberg Tribunal G.A. Res. 95 (I) U.N. Doc. A/64 Add. 1 (1946); Principles of International Law Recognized in the Charter of the Nuremberg Tribunal and in the Judgment of the Tribunal (International Law Commission), 5 U.N. GAOR (No. 12), 11 U.N. Doc. $A / 1316$ (1950). Also, in 1968, the United Nations adopted the Condention on the NonApplicability of Statutory Limitations to War Crimes and Crimes Against Humanily, 26 Nov. 1968, 754 U.N.T.S. 73, reprinted in 8 I.L.M. 68 (1969).

46. See Frank \& Rodley, Paust \& Plaustein, supra note 27.

47. See Timerman, Fear Returns to Argentina New York Times, Jan. 5, 1991, at 13, col. 1 . 
security were, and certainly as they now appear to be, the argument of national security was frequently used to rationalize the commission of international crimes ranging from aggression to torture. Even now, public officials in countries which resort to, or allow torture, rationalize it on the grounds of national security or public necessity. ${ }^{18}$ Strange as it may seem, the efforts of public officials to shield themselves from accountability, whether heads of state or. simple police officers, has consistently been the same for as long as there is a record of these occurrences. They invariably argue that their action was necessary in order to protect or save the nation, or to advance its vital or national security interests.

Another argument advanced against such a court, as well as another risk perceived by public officials, is the apprehension that an international adjudication body can, for purely political reasons, embarrass governments and public officials. But surely sufficient safeguards could be developed to prevent such possibilities, much as certain mechanisms have been developed in domestic legal systems to avoid abuse of power through prosecutorial misconduct and abuse of prosecutorial discretion. Such issues as well as other legal-technical issues cannot be raised $a$. priori to oppose the realization of the idea. They are valid concerns to be raised in the context of drafting the norms and provisions of an international criminal court system so as to develop appropriate safeguards. It is, therefore, more likely that this argument is raised in order to obfuscate the fact that the former one (to shield public officials) is the real reason for the opposition to the idea.

Practical questions are also raised with frequency and have a ring of authenticity to them, particularly to the non-initiated. Among these questions are: where to locate the Court; how to secure the presence of the accused to stand trial; how to select judges, etc. These and other practical questions are no different than those which faced the drafters of the 1899 Hague Convention establishing the Permanent Court of Arbitration, ${ }^{49}$ or those of the 1920 Permanent Court of International Justice and of the 1945 International Court of Justice, respectively part of the League of Nations and United Nations Charters. Granted, these tribunals were not set up for purposes of individual criminal prosecutions and that there are peculiar problems to this type of adjudication, but

48. See generally Bassiouni \& Derby, The Crime of Torture, in 1 M.C. Bassiouni, International Criminal Law: Crimes 363 (1986); Torture in the Eighties (An Amnesty International Report, 1984).

49. Convention for the Pacific Settlement of Disputes, July 29, 1899, 32 Stat. 1799. 
political sensitivities about all forms of international adjudication are similar. That is why both the PCIJ and the ICJ provide for the MemberStates the choice of compulsory or voluntary submission to jurisdiction. ${ }^{50}$ In the case of an international criminal court having jurisdiction over individuals, it would seem that these political sensitivities should be of a lesser nature, except, of course, when it comes to prosecuting public officials for crimes having political overtones or which are committed pursuant to state-policy and particularly if the international criminal court were to have exclusive jurisdiction.

The Draft Statute for an International Criminal Tribunal, which I prepared in 1980 and which was revised and reviewed by the 1990 Siracusa Committee of Experts and then submitted to the Eighth United Nations Congress, ${ }^{51}$ addresses these concerns without compromising the basic values and goals sought to be achieved by such a Tribunal. Clearly, other solutions to practical and legal technical questions can be developed, but the point is that these problems are not as difficult to resolve as some government officials claim. They are not, therefore, a valid reason for the refusal of establishing an international criminal court.

Legal-technical issues are easily resolvable and many thoughtful models have been developed by the League of Nations, the United Nations, non-governmental organizations and individual scholars. ${ }^{52}$ (Some of these questions are discussed below when the "Proposed Model"' is examined.)

\section{Recent Developments}

In the last three years, the question of establishing an international criminal court has emerged at the highest political levels in the world and renewed interest has been expressed by world leaders and by the United Nations. ${ }^{53}$

As early as 1987, President Gorbachev expressed support for such a court, but with jurisdiction limited to terrorism..$^{54}$ In the United

50. See Statute of the International Court of Justice, art. 36. For a case which examines the Court's jurisdictional issues, see Military and Paramilitary Activities In and Against Nicaragua 1986. I.C.J. 14. See genetally, Maier, Appraisals of the ICJ's Decision: Nicaragua v. United States, 81 AM. J. INI'L L. 77 (1987).

51. See supra notes $37-39$.

52. See e.g., supra notes 32, 33 and 35, infro note 71 and the Appendix.

53. See supra notes $36-42$ and accompanying text and infro notes 54-56, 65 and accompanying text.

54. Pravda Sept. 16, 1987. 
States, Senator Arlen Specter has been, since 1986, a constant advocate of such a court, ${ }^{55}$ as have Congressmen Leach and Kastenmeier in the House..$^{56}$ In fact, the United States Congress has urged the establishment of an international criminal court, but only with regard to international terrorism and international trafficking in drugs. In 1986, as part of the Omnibus Diplomatic Security and Antiterrorism Act of 1986, ${ }^{57}$ Congress called upon the President to "consider including on the agenda for these negotiations [regarding an international convention to prevent and control all aspects of international terrorism,] the possibility of eventually establishing an international tribunal for prosecuting terrorists." 58 Also, in 1988, Congress passed the Anti-Drug Abuse Act of $1988,{ }^{59}$ which also asserts the need for some sort of international tribunal to handle cases of drug trafficking. It provides that:

It is the sense of the Senate that the President should begin discussions with foreign governments to investigate the feasibility and advisability of establishing an international criminal court to expedite cases regarding the prosecution of persons accused of having engaged in international drug trafficking or having committed international crimes. ${ }^{60}$

Even more recently, Congress, at the behest of Senator Specter, amended the "Foreign Operations, Export Financing, and Related Programs Appropriations Act, 1991," "61 and provided:

(a) The Congress finds that-

55. Supra note 37; see also Appendix II.

56. H.R. Con. Res. 66, 100th Cong., 2d Sess. (1989). In recognition of the efforts of Congressmen Leach and Kastenmeier, Senator Specter stated in the Congressional Record, October 25, 1990, supra note 37:

First and foremost, I wish to recognize the great contribution made by Congressman Jim Leach, Congressman Bob Kastenmeier and their staffs on behalf of this legislation regarding the creation of an international criminal court. Their efforts in the House of Representatives have served as inspiration for this Senator to continue ahead in the unchartered waters surrounding this issue. Their House Concurrent Resolution 66, which they introduced on March 2, 1989, served as a source of reassurance to my past resolutions and in my crafting of amendment No. 3068.

57. Puв. L. No. 99-399 (1986).

58. Id., Title XII - Criminal Punishment of International Terrorism; S 1201 (Encouragement for Negotiation of a Convention) (d).

59. Pus. L. No. 100-690 (1988). Court) (a).

60. Id., Title IV International Narcotics Gontrol, $\$ 4108$ (International Criminal

61. Pub. L. No. 101-513 (1990). 
(1) the international community has defined as criminal conduct in various international conventions, certain acts such as war crimes, crimes against humanity, torture, piracy and crimes on board commercial vessels, aircraft hijacking and sabotage of aircraft, crimes against diplomats and other internationally protected persons, hostage-taking, and illicit drug cultivation and trafficking;

(2) in spite of these international conventions, the effective prosecution of those who commit criminal acts has been seriously obstructed in certain cases because of problems of extradition and differences between the legal and judicial systems of individual nations;

(3) the jurisdiction of the International Court of Justice extends only to cases involving governments, and not to individual criminal cases;

(4) the concept of an international criminal court has been under consideration in the United Nations and other international fora for many years, including proposals and reviews undertaken in 1990 by the United Nations General Assembly, the International Law Commission, and the Eighth United Nations Congress on the Prevention of Crime and the Treatment of Offenders;

(5) the international military tribunals established in Nuremburg, Germany, and Tokyo, Japan, following World War II also establish a precedent for international criminal tribunals; and

(6) there is growing movement among nations of the world to formulate their economic, political and legal systems on a multilateral basis.

(b) It is the sense of Congress that-

(1) the United States should explore the need for the establishment of an International Criminal Court on a universal or regional basis to assist the international community in dealing more effectively with criminal acts defined in international conventions; and

(2) the establishment of such a court or courts for the more effective prosecution of international criminals should not derogate from established standards of 
due process, the rights of the accused to a fair trial and the sovereignty of individual nations.

(c) The President shall report to the Congress by October 1,1991 , the results of his efforts in regard to the establishment of an International Criminal Court to deal with criminal acts defined in international conventions.

(d) The Judicial Conference of the United States shall report to the Congress by October 1, 1991, on the feasibility of, and the relationship to, the Federal judiciary of an International Criminal Court. ${ }^{62}$

As for the Bush Administration, it has stressed international cooperation against terrorism and trafficking in drugs, but it seems, at this point, reluctant to support an international court to prosecute such offenders. ${ }^{63}$ (For a chronology of U.S. developments regarding an international criminal court see Appendix II.)

As for other countries, France and the United Kingdom have an ambiguous position. At the 1990 Eighth United Nations Congress on Crime Prevention and Treatment of Offenders, their representatives joined efforts to lobby other Western European countries against a resolution calling for the establishment of an international criminal court, though both countries had previously voted favorably on two resolutions in the General Assembly in 1989-90 supporting such an idea. $^{64}$ On the positive side, sixteen Caribbean and Latin American countries have been supporting the idea since 1989. Trinidad and Tobago has been in the forefront of this question, led by Prime Minister A.N.R. Robinson, and since 1990, Columbia's President C. Oaviria Trujillo has also strongly supported the idea. ${ }^{65}$ In response to such

62. Id., \$599 E (International Criminal Court).

63. On terrorism and drugs, see e.g., Bassiouni, Effective National and Intemational Action Against Organized Crime and Terrorist Criminal Activities, 4 EMoRY INT'L L. REv. 9 (1990); Bassiouni, Critical Reflections of International and National Control of Drugs, 18 DEN. J. INT'L L. \& Por. 311 (1990).

64. See supra note 36 . At the Eighth United Nations Congress, see supra notes 38-40 and accompanying text; a number of countries made statements supporting the idea of an international criminal court. They are: Brazil, Colombia, Czechoslovakia, Israel, Poland, Romania, Trinidad and Tobago, U.S.S.R. and Yugoslavia.

65. Agenda Item 152, referred to supra note 36 , was introduced at the request of Trinidad and Tobago, see G.A. Res. A/44/195 (1989) and in the Annex, an explanatory memorandum by Ambassador Margorie Thorpe stated, in part, as follows:

The desirability and feasibility of an international criminal court to deal 
strong interest, the Organization of American States has begun studying the possibility of a Regional Criminal Court for the Americas. ${ }^{66}$ The Caribbean and Latin American countries show particular eagerness for such a Court and they are understandably dismayed to see the disinterest and opposition of other countries (particularly the U.S.) that are quick to accuse them of not doing enough to control international trafficking in drugs and terrorism.

Current international interests, however, seem to focus only on drugs and terrorism. What is needed instead is an international criminal

with international criminal offences was the subject of much discussion even before the establishment of the Nuremberg International Military Tribunal on 8 August 1946. It was envisaged then that the jurisdiction of an international criminal court would cover individuals charged with violations of certain rules of international law such as genocide. Such a proposal was formalized in 1951 and revised in 1954 by the Committee on International Criminal Jurisdiction, established pursuant to General Assembly resolutions 489 (V) of 12 December 1950 and 687 (VII) of 5 December $1952 \ldots$

The establishment of an international criminal court with jurisdiction to prosecute and punish individuals and entities who engage in, inter alia, the illicit trafficking in narcotic drugs across national borders would serve to bolster the legal process whereby such offenders are prosecuted and punished and would also contribute substantially to the progressive development and codification of international law.

With regard to Columbia, as Senator Specter notes in the Congressional Record:

Colombia is a vivid case in point. Extraditions to the United States have had some positive effect on traffickers. But, these same extraditions represent a serious political problem for the leadership of Colombia. Thus, in his August 7, 1990, Inauguration address, President Cesar Oaviria Trujillo vowed to "explore the possibility of creating an international or regional criminal jurisdiction to fight narco-trafficking and other related crimes that surpass international borders."

136 Conc. Rec. S18160 (daily ed. October 25, 1990).

66. The Inter-American Juridical Committee of the OAS at its 1990 session, held in Rio de Janeiro, Brazil (see document OEA/Ser. G, CP/doc.2113/90, Nov. 7, 1990, page 53). The motion to examine this topic was presented by the Argentine member of the Committee, Dr. Jorge R. Vanossi, who was subsequently appointed rapporteur together with Professor M. Vieira from Uruguay. In his introductory statement, Dr. Vanossi made reference to the work undertaken by the International Institute of Higher Studies in Criminal Sciences, and to the preparatory work submitted by Dr. Bassiouni (see 1990 Session of the Inter-American Juridical Committee, August 18 meeting, Minute No. 12). These documents will be an important source for the Committee, which is expected to begin examination of the topic at the 1991 JulyAugust session. This information was provided by Ambassador Hugo Caminos, Assistant Secretary General for Legal Affairs, who is following this question at the OAS. 
court with universal jurisdiction to prosecute all or most of the 22 categories of international crimes covered by conventional and customary international law, including, but not limited to: ${ }^{67}$ aggression (crimes against peace); war crimes; crimes against humanity; genocide; apartheid; slavery and slave-related practices; torture; unlawful human experimentation; piracy; hijacking and sabotaging of aircraft; kidnapping of diplomats and other internationally protected persons; taking of hostages; and, criminal damage to the environment. The International Law Commission has taken such a position in its 1990 Report to the General Assembly, though the list of international crimes it has developed is different from the one proposed above by this writer. ${ }^{68}$

The ILC's 1990 position on such a Court is stated as follows:

\section{Competence of the Court}

(a) Jurisdiction limited to the crimes mentioned in the Code or
jurisdiction as to all international crimes? (i) Versions submitted

5. On this topic, the Special Rapporteur submits the following versions:

Version A: There is established an International Criminal Court to try natural persons accused of crimes referred to in the draft Code of crimes against the peace and security of mankind. Version B: There is established an International Criminal Court to try natural persons accused of crimes referred to in the draft Code of crimes against the peace and security of mankind, or other offences defined as crimes by the other international instruments in force.

67. See M.C. Bassiouni, International Crimes: Digest/Index of InternaTIONAL INSTRUments 1815-1985 (1986). See also statement of Senator Specter, supra note 37:

Modern international criminal law can be said to have commenced in 1815 at the Congress of Vienna with efforts to abolish slavery. Since then 317 international instruments on substantive international criminal law have been agreed to covering international crimes such as aggression, war crimes, crimes against humanity, apartheid, torture, piracy on board commercial vessels, aircraft hijacking, kidnapping of diplomats and other internationally protected persons, taking of civilian hostages and environmental damages to name a few.

68. See the International Law Commission's latest report (from its Forty-First Session) to the General Assembly, U.N. Doc. A/CN.4/L.443 (1990). 


\section{(ii) Commentary}

6. The question is whether international criminal jurisdiction will be limited to the crimes referred to in the draft Code of crimes against the peace and security of mankind, or whether it will also encompass other international crimes which do not fall within that category. As is well known, the Code does not cover all international crimes. Among those not mentioned therein are the dissemination of false or distorted news, or false documents, by persons knowing that they will have an adverse effect on international relations; insults to a foreign State; the counterfeiting of currency; practiced by one State to the detriment of another State, and the theft of national or archaeological treasures; the destruction of submarine cables; international trafficking in obscene publications, etc.

7. Accordingly; the concept of an international crime is broader than that of a crime against the peace and security of mankind; it covers a wider field which includes all other international crimes in addition to those defined in the draft Code.

8. The question, therefore, is whether the jurisdiction of the Court is limited to crimes against the peace and security of mankind, or whether the Court will deal with all international crimes.

9. It would seem preferable to confer the broadest possible jurisdiction upon the Court; otherwise, it would be necessary to establish two international criminal jurisdictions, which would lead to complications.

(b) Necessity or non-necessity of the agreement of other States

(i) Versions submitted

Version $A$ : No person shall be tried before the Court unless jurisdiction has been conferred upon the Court by the State in which the crime was committed, or by the State of which such person is a national, or by the State against which the crime was directed, or of which the victims were nationals.

Version B: Any State may bring before the Court a complaint against a person if the crime of which he is accused was committed in that State, or if it was directed against that State, or if the victims are nationals of that State. If one of 
the said States disagrees as to the jurisdiction of the Court, the Court shall resolve the issue.

(ii) Commentary

11. Version $A$ is based on article 27 of the draft statute prepared by the 1953 Committee on International Criminal Jurisdiction. ${ }^{69}$ Is it appropriate? From the legal point of view, nothing prohibits a State from punishing crimes against its own security, even if such crimes are committed abroad by foreigners. Moreover, in the vast majority of cases, this solution would lead to requesting the consent of Governments guilty of having organized or tolerated criminal acts. ${ }^{70}$

Such a court is not only possible, it is quite feasible. All of the foreseeable problems and difficulties have been thoughtfully dealt with by a number of experts who have prepared detailed studies and examined alternative solutions to the various legal and practical questions. ${ }^{73}$

69. See Report of the 1953 Committee on International Criminal Jurisdiction, Official Records of the General Assembly, Ninth Session, Supplement No. 12 (A/2645), annex, article 27.

70. International Law Commission, Forty Second Session, U.N. Doc. A/CN.4/ 430/Add.1 (1990) Eighth Report on the Draft Code of Crimes Against the Peace and Securily of Mankind.

1 71. See e.g., B. Ferencz, An International Criminal Court (1980), which provides a documentary examination of the historical evolution of international crimes and the establishment of an international criminal court. Some scholars see the problem both in terms of the political will of the most powerful governments and of the lack of scholarly consensus on the broader issue of the scope and content of international criminal law. See e.g., Friedlander, The Enforcement of Intemational Criminal Law: Fact or Fiction, 17 CASE W. REs. J. INT'L L. 79 (1985) (wherein the author re-examines Georg Schwarzenberger's query about the existence of international criminal law); Friedlander, The Foundations of Intemational Criminal Law: A Present Day Inquiny, 15 CASE W. Res. J. INr'L L. 13 (1983); Green, Is There an Intemational Criminal Law, 21 Alberta L. REv. 251 (1983); Green, New Trends in International Criminal Law, 11 Iss. Y.B. Hum. RTs. 9 (1981); Green, An International Criminal Code - Now? 3 Dalmousie L.J. 560 (1976); Dinstein, International Criminal Law, 5 IsR. Y.B. Hum. Rrs. 55 (1975); Wright, The Scope of Intemational Criminal Law, 15 VA. J. INT'L L. 562 (1975). See generally Derby, A Framework for Intemational Criminal Law, in 1 M.C. Bassioum, INTERNational. Criminal Law: Crimes 33 (1986); Schwarzenberger, The Problem of Inlemational Criminal Law, 3 Current Legal Problems 263 (1950); Report of the International Law Commission on Questions of International Criminal Jurisdiction, U.N. Doc. A/CN.4/15 (1950). See also Bassiouni \& Derby, Final Report on the Establishment of an Intemational Criminal Court for the Implementation of the Apartheid Convention and Other Relevant Instruments, 9 Hofstra L. Rev. 523 (1981); Kos-Rabcewicz-Zubkowski, La Creation d'une Cour Penal Intemationale et l'Administration Internationale de la Justice, 1977 CAN. Y.B. INT'L L. 253; 


\section{Alternative Models}

The formulae presented in the scholarly literature and proposals advanced by different organizations range from the position of the Association Internationale de Droit Pénal, which since 1926, has urged the establishment, by way of a treaty-statute (much like the Nuremberg Charter and Tokyo Statute), of a universal, as opposed to a regional, international criminal court having jurisdiction over all international crimes, to that of the International Law Association, which has advocated an International Commission of Inquiry (See Appendix I). Alternative approaches are based on an expanded concept of jurisdiction discussed, since the 1970's, within the Council of Europe under the rubrique " $L$ 'Espace Judiciaire Européen", which is still under consideration, and which has inspired the Commission of the Andean Parliament

Kos-Rabcewicz-Zubkowski, The Creation of an Intemational Criminal Court, in International Terrorism and Political Crimes 519 (M.C. Bassiouni ed. 1975); Grebing, La Creation d'une Cour P'́nal Intemationale: Bilan et Perspectives, 45 Rev. INT'Le de DroIt PÈnal 435 (1974); Miller, Far Beyond Nuremberg: Steps Toward an International Criminal Jurisdiction, 61 KY. L.J. 925 (1973); Dautricourt, The Concept of International Criminal Court Jurisdiction - Definition and Limilations of the Subject, in 1 A TREATISE ON INTERnational Criminal Law 636 (M.C. Bassiouni \& V.P. Nanda eds. 1973); J. Stone \& R. Woetzel, Toward a Frasible International Criminal Court (1970); Klein \& Wilkes, United Nations Draft Statute for an Intemational Criminal Court: An American Evaluation, in International Criminal Law 573 (G.O.W. Mueller \& E. Wise eds. (1965)); Ambion, Organization of a Court of International Criminal Jurisdiction, 29 PHIL $L$. J. 345 (1954); P. Carjeu, Projet D'une Juridiction Penale Internationale (1953); Wright, Proposal for an International Criminal Court, 46 AM. J. INT'L L. 60 (1952); Finch, Draft Statule for an Intemational Court, 46 AM. J. INT'L L. 89 (1952); Yeun-Li, The Establishment of an International Criminal Jurisdiction: The First Phase, 46 AM. J. INT'L L. 73 (1952); A. Sottile, The Problem of the Creation of a Permanent International Criminal Gourt (1951); Pella, Towards an International Criminal Court, 44 AM. J. INT'L L. 37 (1950); Pella, Plan d'un Code Repressif Mondial, 6 Rev. Inr'le de DroIt PÉnal 148 (1935). See Symposium issue 45 Rev. INT'Le de Drort PEnal, Nos. 3-4 (1974) (containing contributions for the Fifth U.N. Congress on Crime Prevention and the Treatment of Offenders, Geneva, 1-12 Sept. 1975; Symposium issue 20 REV. INT'LE de Droit PÉnal, No. 1 (1949) (regarding the various U.N. drafts); Symposium issue (with articles by Donnedieu de Vabres and Francis Biddle) 19 REv. INT'LE DE Droit Penal, No. 1 (1948); Symposium issue 17 Rev. Int'Le de Droit PÉnal, Nos. 3-4 (1936). See Drafi Statute for an International Commission of Criminal Inquiry and a Draft Statute for an International Criminal Court, International Law Association, 60th Conference, Montreal, Aug. 29 - Sept. 4, 1982, in Report of the 60th Conference of the International Law Association (1983); Draft Statute for an Intemational Criminal Court, Work Paper, Abidjan World Conference on World Peace Through Law, Aug. 26-31 (1973); Draft Statute for an International Criminal Court, Foundation for the Establishment of an International Criminal Court (Wingspread Conference, Sept. 1971). 
to consider the "Espacio Judiciario Andino."72 These approaches substitute expanded regional criminal jurisdiction for the idea of regional or international adjudicating bodies. Thus, national criminal courts and national structures of administration of criminal justice would remain competent but they would be able to act even when the crime was not committed within their territory. In fact, these schemes are not really designed to expand the adjudication system, but they are a subterfuge for allowing law enforcement agencies, now limited by territorial jurisdiction, to operate outside it. These approaches, while strengthening law enforcement, do not accomplish the many goals of international or regional adjudication, and consequently, should not be regarded as valid alternatives. In addition, these schemes are fraught with dangers to procedural safeguards on the extra-territorial activities of law enforcement.

The establishment of an international criminal court, whether universal or regional, can be based on exclusive jurisdiction for certain crimes or on concurrent or alternative jurisdiction with that of the state having criminal jurisdiction. The jurisdictional mechanisms are, of course, to be established by the treaty-statute.

The establishment of an international criminal court could admittedly be based on various models including, but not limited to:

i. Expanding the jurisdiction of the International Court of Justice to include questions of interpretation and application of conventional and customary international criminal law, and providing for compulsory jurisdiction under Article 36 of the Statute of the International Court of Justice for disputes between states arising out of these questions;

ii. Establishing an international commission of inquiry, either as an independent organism, as part of the international criminal court or as an organ of the United Nations. Such a commission would investigate and report on violations of international criminal law, taking into account the proposal of the International Law Association and existing United Nations experiences with fact-finding and inquiry bodies which have

72. See generally, Graefrath, Universal Criminal Jurisdiction and an Intemational Criminal Court, 1 European J. INT'L L. 67, $81-85$ (1990); see also Mosconi, L'Accordo di Dublino del 4/12/79, Le Comunita Europee e La Repressione del Terrorisimo, in LA LegisLazione Penale 543 (1986); Van Den Wyngaert, L'Espace Judiciarie Européen Face á L'Euroterrorime at la Saudegarde des Droils Fondamentaux, 3 Rev. Int'le de Criminologuie er de Police Tzchnique 289 (1980). 
developed over the years;

iii. Establishing an international (universal) criminal jurisdiction along the lines of the 1953 United Nations Draft Statute for Establishment of an International Criminal Court ${ }^{73}$ or the 1980 Draft Statute for the Establishment of an International Criminal Jurisdiction to Implement the International Convention on the Suppression and Punishment of Apartheid Convention; ${ }^{74}$

iv. Establishing Regional International Criminal Courts.

\section{The Proposed Model}

This model could be used for a (Universal) International Criminal Court, as well as for a Regional International Criminal Court, the latter being only limited in geography to StateParties from the region. The highlights of this proposal are as follows:

1. Establishment of the Tribunal

a. The Tribunal would be established pursuant to a multilateral convention (hereinafter referred to as the "Convention") open to all States.

b. The States-Parties to the Convention would agree on the establishment of the Tribunal whose location will be determined by the Convention.

c. The Tribunal would have an independent international legal personality and would sign a host-country agreement with the host-state. The Tribunal will thus have extra-territoriality for its location and immunity for its personnel.

d. The Tribunal's costs and facilities, including detentional facilities would be paid on a pro-rata basis by the State-Parties to the convention.

e. The Tribunal as an international organization would be granted jurisdiction by the State-Parties to prosecute certain specified

73. See supra note 33.

74. See supre note 35. 
offences embodied in the Annex to the Convention and would have the authority to detain those accused, and those convicted of the charges.

2. Jurisdiction of the Tribunal and Applicable Law

a. The jurisdiction of the Tribunal would be over persons for those offences defined in the Annex to the Convention, as amended, from time to time. [This would permit expanding the list of crimes depending upon need, and also to allow StateParties to acquire confidence in the Tribunal.]

b. The Court could have exclusive jurisdiction for some crimes and derivative jurisdiction over others by virtue of a transfer of the proceeding ${ }^{75}$ from a State-Party to the Convention, provided the State-Party has jurisdiction on the basis of territoriality, active or passive personality. [This would avoid the sovereignty problems that some claim would exist if the Tribunal would have exclusive or original jurisdiction. It would also serve to circumvent problems of mandatory national prosecution if the laws of the state where the crime occurred so require. Transfer of proceedings may also be done in a way that would be similar in legal nature to a change of venue. This approach coupled with the possibility of transfer of the offender back to the state where the crime occurred would also avoid many domestic legal difficulties.] Nothing, however, precludes the State-Parties from conferring exclusive jurisdiction for certain crimes to the Tribunal. Thus, each State-Party that has original jurisdiction based on territoriality, active or passive personality would not lose jurisdiction, but merely transfer the criminal proceedings to the Tribunal.

c. To avoid problems of what substantive law to apply, the Tribunal would use the substantive law of the transferring state or of the state where the offence was committed and its own procedural rules which would be part of the Convention and promulgated prior to the Tribunal's entry into function. ${ }^{76}$ [The

75. See e.g., European Convention on the Transfer of Proceedings in Criminal Matters, 15 May 1972, E.T.S. No. 73. See also M.C. Bassiouni \& E. Müller-Rappard, European Inter-State Co-Operation in Cruminal Matrers (1987).

76. The procedural rules would be on the basis of general principles of international law and in accordance with internationally protected human rights, particularly the International Covenant on Civil and Political Rights, G.A. Res. 2200A (XXI), 
Tribunal's procedural rules would incorporate international human rights standards of due process and assure uniformity of procedural treatment of all persons. The application of the substantive law of the state where the offence was committed is fair, and would assuage any exacerbated feelings of sovereignty that such a state may have in allowing the Tribunal to prosecute those accused of committing crimes in their territory.]

3. Prosecution

a. The Tribunal's Procurator-General would act as the Chief Prosecutor, but could be assisted by a prosecuting official of the transferring state whose law is to be applied. [This too would reinforce the change of venue approach and prevent the claim that State-Parties totally relinquished jurisdiction.]

b. Prosecution would commence on the basis of a criminal complaint brought by a State-Party (thus supporting State-Parties' sovereignty). In addition, a State-Party that does not have subject matter or in personam jurisdiction, or that does not wish to bring a criminal complaint within its own jurisdiction, may petition the Procurator-General of the Tribunal to inquire into the potential direct prosecution by the Tribunal. [This relieves a State-Party from pressures in certain cases.] In such cases, the request by a State-Party would be confidential, and only after the Procurator-General of the Tribunal has deemed the evidence sufficient will the case for prosecution be presented to an Inquiry Chamber of the Tribunal in camera for its action. In such a situation, the Tribunal's Procuracy and the Inquiry Chamber would be acting as an international judicial board of inquiry. ${ }^{77}$ Once the Inquiry Chamber has decided to allow

16 Dec. 1966 and the Inter-American Convention on Human Rights, O.A.S. Official Records Ser. K/XVI/1.1 Doc. 65, Rev. 1, Cor. 1 (Jan. 7, 1970), 22 Nov. 1969; and the European Convention for the Protection of Human Rights and Fundamental Freedoms, Nov. 4, 1950, 213 U.N.T.S. 262, No. 5.

77. See "Draft Statute for an International Commission of Criminal Inquiry and a Draft Statute for an International Criminal Court," International Law Association, 60th Conference, Montreal, Aug. 29-Sept. 4, 1982, in Report of the 60th Conference of the Intemational Law Association (1983). For efforts to initiate such a commission see U.N. Security Council Resolution 672 (1990) and Bassiouni, Iraq's Human-Rights Toll, Christian Science Monitor, Nov. 26, 1990 at 19, which provides in part:

Recently, the Security Council resolved to establish an ad hoc commission to investigate Israel's killing of some 20 Palestinians at Jerusalem's Temple 
prosecution, it would authorize the Procurator-General to issue an indictment and request the surrender of the accused from the State where the accused may be found. If that state is a State-Party, it would be bound to surrender the accused. Any other state may do so by the special treaty with the Tribunal or on the basis of comity.

c. The Convention would include provisions on surrendering the accused to the Tribunal and providing the Tribunal with legal assistance (including administrative and judicial assistance) for the procurement of evidence, both tangible and testimonial. ${ }^{78}$

d. By virtue of the Convention, an indictment by the Inquiry Chamber, will be recognized by all State-Parties in much the same way as other forms of recognition of foreign penal judgments. [National legislation could be amended whenever necessary to provide for such recognition.]

4. Conviction

a. Upon conviction, the individual may be returned to the surrendering state, which will carry out the sentence on the basis of provisions in the Convention, which would be in the nature of "transfer of prisoners" agreements. ${ }^{79}$ Alternatively, the convicted person can be transferred to any other State-Party on

Mount. Appropriate as that is, no one who views human rights as universal can fail to note that the same measure was not resolved for Iraqi violations - or, for that matter, for other more serious ones. Lest one forgets, 1.5 million people have been killed by the Khmer Rouge in Cambodia, with muted condemnation by powers quick to condemn Israel and now Iraq. We must not have different scales to weigh human-rights violations, scales dependent upon who the violator or the victim may be.

The tragic incidents in the Middle East can be an opportunity to enhance human-rights protections by serving as an impetus to the establishment of an impartial, permanent fact-finding commission. The time has come to do something more than express selective verbal condemnations.

78. See e.g., The European Convention on Mutual Legal Assistance, Apr. 20, 1959, E.T.S. No. 30; see M.C. Bassiount \& E. Mûller-Rappard, supra note 75 . See generally Ellis \& Pisani, The United States Treaties on Mutual Assistance in Criminal Matters in 2 M.C. Bassiount, International Griminal Law: Progedure 151 (1986).

79. See e.g., The European Convention on Transfer of Sentenced Persons, Mar. 21, 1983, E.T.S. No. 112. See Epp, The European Convention on Transfer of Prisoners, in 2 M.C. Bassiouni, International Criminal Law: Procedure 253 (1986), and Bassiouni, Transfer of Prisoners Between the United States, Mexico, and Canada. Id., at 239. See M.C. Bassiouni \& E. Müller-Rappard, supra note 75. 
the same legal basis, or the Tribunal may place the convicted person in its own detentional facilities, which would be established by the Convention in accordance with a host-state agreement between the Tribunal and the state wherein the detentional facility would be established. [This provides a first option to the State-Party where the crime was committed, to execute the sentence, as well as a second option of allowing the transfer to another State-Party in order to avoid the pressures and problems that the detention of certain offenders can engender or to have the Tribunal execute the sentence. A number of States are already bound by treaties on transfer of prisoners and the practice is well under way among more than thirty countries.]

b. A conviction by the Tribunal would be recognized by all StateParties on the basis of a provision in the Convention establishing recognition for such judgments similar to existing agreements on the same subject.

Other states may recognize such a judgment by special arrangement with the Tribunal or on the basis of their domestic laws which could be made to include recognition of the Tribunal's penal judgments. [This would expand the network of cooperating states to include those states which may not become State-Parties but who would be willing to cooperate with the Tribunal in some respect.]

5. Composition of the Court

a. The Tribunal would consist of as many judges as there are State-Parties to the Convention, but not less than thirteen. There would be at least four Chambers of three judges each and a Presiding Judge. The judges would be drawn by lot and sit in rotation on the various chambers.

b. One of the chambers would act as the Inquiry Chamber while the other chambers would be adjudicating chambers.

6. Appeal

To provide for the right of appeal, the Tribunal sitting en banc with a panel of nine judges would hear appeals excluding those judges who decided the merits of the case.

7. Selection of Judges

Each State-Party would appoint a judge from the ranks of its judiciary or from distinguished members of the bar or from 
academia. The judges would be persons of high competence, knowledgeable in international criminal law, and of high moral character. Appointment of judges and their tenure would be established by the Convention.

8. Rules of the Tribunal

The Tribunal would be authorized to enact rules of practice and procedures before it.

9. Standing Committee of State-Parties

The State-Parties would hold an annual conference to review the Tribunal's work and the Convention for purposes of amending it whenever needed and to ensue full compliance by the State-Parties.

10. The Organs of the Tribunal

These organs shall consist of:

\section{The Court}

1. The Court shall consist of twelve judges, no more than two of whom shall be of the same nationality, who shall be elected by the Standing Committee of States-Parties from nominations submitted thereto.

2. Nominees for positions as judges shall be of distinguished experts in the fields of international criminal law or human rights and other jurists qualified to serve on the highest courts of their respective states who may be of any nationality or have no nationality.

3. Judges shall be elected by secret ballot and the Standing Committee of States-Parties shall strive to elect persons representing diverse backgrounds and experience with due regard to representation of the major legal and cultural systems of the world.

4. Elections shall be coordinated by the Secretariat under the supervision of the presiding officer of the Standing Committee of States-Parties and shall be held whenever one or more vacancies exist on the Court.

5. Judges shall be elected for the following terms: four judges for four-year terms, four judges for six-year terms, and four judges for eight-year terms. Judges may be re-elected for any term at any time available. 
6. No judge shall perform any public function in any state.

7. Judges shall have no other occupation or business than that of judge of this Court. However, judges may engage in scholarly activity for remuneration provided such activity in no way interferes with their impartiality and appearance of impartiality.

8. A judge shall perform no function in the Tribunal with respect to any matter in which he may have had any involvement prior to his election to this Court.

9. A judge may withdraw from any matter at his discretion, or be excused by a two-thirds majority of the judges of the Gourt for reasons of conflict of interest.

10. Any judge who is unable or unwilling to continue to perform functions under this statute may resign. A judge may be removed for incapacity to fulfill his functions by a unanimous vote of the other judges of the Court.

11. Except with respect to judges who have been removed, judges may continue in office beyond their term until their replacements are prepared to assume the office and shall continue in office to complete work on any pending matter in which they were involved even beyond their term.

12. The judges of the Court shall elect a president, vicepresident and such other officers as they deem appropriate. The president shall serve for a term of two years.

13. Judges of the Court shall perform their judicial functions in three capacities:

a. 'Sitting with other judges as the Court en banc;

b. Sitting in panels of three on a rotational basis in chambers; and

c. Sitting individually as supervisors of sanctions.

14. The salary of judges shall be equal to that of the judges of the International Court of Justice.

15. The Gourt en banc shall, subject to the provisions of this Statute, adopt rules governing procedures before its chambers and the Court en banc, and provide for establishment and rotation of chambers.

16. The Court en banc shall announce its decisions orally in 
full or in summary, accompanied by written findings of fact and conclusions of law at the time of the oral decision or within thirty days thereafter, and any judge so desiring may issue a concurring or dissenting opinion.

17. Decisions and orders of the Court en banc are effective upon certification of the written opinion by the Secretariat, which is to communicate such certified opinion to parties forthwith.

18. The Court en banc may, within thirty days of the certification of the judgment, enter its decisions without notice.

19. No actions taken by the Tribunal may be contested in any other forum than before the Court en banc, and in the event that any effort to do so is made, the Procurator shall be competent to appear on behalf of the Tribunal and in the name of all States-Parties of this Statute to oppose such action.

20. States-Parties agree to enforce the final judgments of the Court in accordance with the provisions of this Statute.

\section{The Procuracy}

1. The Procuracy shall have the Procurator as its chief officer and shall consist of an administrative division, an investigative division and a prosecutorial division, each headed by a deputy Procurator, and employing appropriate staff.

2. The Procurator shall be elected by the Standing Committee of States-Parties from a list of at least three nominations submitted by members of the Standing Committee, and shall serve for a renewable term of six years, barring resignation or removal by two-thirds vote of the judges of the Court en banc for incompetence, conflict of interest, or manifest disregard of the provisions of this Statute or material rules of the Tribunal.

3. The Procurator's salary shall be the same as that of the judges.

4. The deputy procurators and all other members of the Procurator's staff shall be named and removed by the Procurator at will.

\section{The Secretariat}

1. The Secretariat shall have as its chief officer the Secretary, 
who shall be elected by a majority of the Court sitting en banc and serve for a renewable term of six years barring resignation or removal by a majority of the Court sitting en banc for incompetence, conflict of interest or manifest disregard of the provisions of this Statute or material rules of the Tribunal.

2. The Secretary's salary shall be equivalent to that of the judges.

3. The Secretariat shall employ such staff as appropriate to perform its chancery and administrative functions and such other functions as may be assigned to it by the Court that are consistent with the provisions of this Statute and the rules of the Tribunal.

4. In particular, the Secretary shall twice each year:

a. Prepare budget requests for each of the organs of the Tribunal; and

b. Make and publish an annual report on the activities of each organ of the Tribunal.

5. The Secretariat staff shall be appointed and removed by the Secretary at will.

6. An annual summary of investigations undertaken by the Procuracy shall be presented to the Secretariat for publication, but certain investigations may be omitted where secrecy is necessary, provided that a confidential report of the investigation is made to the Court and to the Standing Committee and filed separately with the Secretariat. Either the Court or the Standing Committee may order by majority vote that the report be made public.

\section{The Standing Committee}

1. The Standing Committee shall consist of one representative appointed by each State-Party.

2. The Standing Committee shall elect by majority vote a presiding officer and alternate presiding officer and such other officers as it deems appropriate.

3. The presiding officer shall convene meetings at least twice each year of at least one week duration, each at the seat of the Tribunal, and call other meetings at the request of a majority vote of the committee. 
4. The Standing Committee shall have the power to perform the functions expressly assigned to it under this Convention, plus any other functions that it determines appropriate in furtherance of the purposes of the Tribunal that are not inconsistent with the Convention, but in no way shall those functions impair the independence and integrity of the Court as a judicial body.

5. In particular, the Standing Committee may:

a. Offer to mediate disputes between States-Parties relating to the functions of the Tribunal; and

b. Encourage states to accede to the Convention.

6. The Standing Committee shall propose to States-Parties international instruments to enhance the functions of the Tribunal.

7. The Standing Committee may exclude from participation representatives of States-Parties that have failed to provide financial support for the Tribunal as required by this Statute or States-Parties that failed to carry out their obligations under this Statute.

8. Upon request by the Procuracy, or by a party to a case presented for adjudication to a chamber of the Court, the Standing Committee may be seized with a mediation and conciliation petition. In that case, the Standing Committee shall within 60 days decide on granting or denying the petition, from which decision there is no appeal. In the event that the Standing Committee grants the petition, Court proceedings shall be stayed until such time as the Standing Committee concludes its mediation and conciliation efforts, but not for more than one year except by stipulation of the parties and with the consent of the Court. ${ }^{80}$

\section{Conclusion}

We no longer live in a world where narrow conceptions of jurisdiction and sovereignty can stand in the way of an effective system of

80. M.C. Bassiouni, supra note 37 , at 236-44, and Draft Statute: Intemational Criminal Tribunal, supra note 38 . 
international cooperation for the prevention and control of international and transnational criminality. If the United States and the Soviet Union can accept mutual verification of nuclear arms controls, then surely they and other countries can accept a tribunal to prosecute not only drug traffickers and terrorists, but also those whose actions constitute such international crimes as aggression, war crimes, crimes against humanity and torture.

Many of the international crimes for which the Court would have jurisdiction are the logical extension of international protection of human rights. ${ }^{81}$ Without enforcement, these rights are violated with impunity. We owe it to the victims of these crimes and to our own human and intellectual integrity to reassert the values we believe in by at least attempting to prosecute such offenders. When such a process is institutionalized, it can operate impartially and fairly. We cannot rely on the sporadic episodes of the victorious prosecuting the defeated and then dismantle these ad hoc structures as we did with the Nuremberg and Tokyo tribunals. The permanency of an international criminal tribunal acting impartially and fairly irrespective of whom the accused may be is the best policy for the advancement of the international rule of law and for the prevention and control of international and transnational criminality.

An international criminal court will surely be established one day. In the meantime, however, we will have to remain with the bitter realization that, if it had existed earlier, it could have deterred certain people and thus prevented some victimization. The conscience of world leaders should be bothered by this prospect, especially when they oppose the idea on the basis that it might infringe on jealously guarded notions of sovereignty.

Justice Robert Jackson as Chief Prosecutor at the Nuremberg International Military Tribunal stated in his opening speech: "This principle of personal liability is a necessary as well as a logical one if International Law is to render real help to the maintenance of peace .... Only sanctions which reach individuals can peacefully and effectively be enforced ... . [T] $]$ he idea that a State ... commits crimes, is a fiction. Crimes always are committed only by persons." 82 It is

81. See Bassiouni, The Proscribing Function of International Criminal Law in the Processes of International Protection of Human Rights, 9 YAle J. WORLd PUB. ORder 193 (1982), reprinted in 1 M.C. Bassioun,, International Criminal Law: Crimes, 15 (1986).

82. 1 The Trial of Grrman Major War Criminals: Proceedings of the International Military Tribunal Sitting at Nuremberg Germany, 82-83 (1946). 
unconscionable at this stage of the world's history, and after so much human harm has already occurred, that abstract notions of sovereignty can still shield violators of international criminal law or that the limited views and lack of vision and faith by government officials can prevent the establishment of such an important and needed international institution. The time has come for us to think and act in conformity with the values, ideals and goals we profess. 


\section{Appendix I}

\section{Establishment of an International Criminal Court}

\section{A. OFFIGIAL TEXTS}

1. Convention for the Pacific Settlement of International Disputes (First Hague, I), signed at The Hague, 19 July 1899, 26 Martens Nouveau Regueil des Traites (2d) 720, 32 Stat. 1779, T.S. No. 342 (entered into force 4 Sept. 1900).

2. Convention Relative to the Establishment of an International Prize Court (Second Hague, XII), signed at The Hague, 18 Oct. 1907, 3 Martens Nouveau Recueil des Traites (3d) 688 (never entered into force).

3. Treaty of Peace with Germany (Treaty of Versailles), signed at Versailles, 28 June 1919, 11 Martens Nouveau Recueil des Traites (3d) 323 (entered into force 10 Jan. 1920).

4. Convention for the Creation of an International Criminal Court, opened for signature at Geneva, 16 Nov. 1937, League of Nations O.J. Spec. in Supp. No. 156 (1938), League of Nations Doc. C.547 (I).M.384(I).1937, (1938) (never entered into force).

5. Agreement for the Prosecution and Punishment of Major War Criminals of the European Axis (London Agreement), signed at London, 8 Aug. 1945, 82 U.N.T.S. 279, 59 Stat. 1544, E.A.S. No. 472 (entered into force, 8 Aug. 1945), ANNEX, Charter of the International Military Tribunal (Nuremberg).

6. International Military Tribunal For the Far East Proclaimed at Tokyo, 19 Jan. 1946 and amended 26 Apr. 1946, T.I.A.S. No. 1589 (entered into force $19 \mathrm{Jan}$. 1946), ANNEX Charter of the International Military Tribunal for the Far East (Tokyo).

7. Control Council Law No. 10 (Punishment of Persons Guilty of -War Crimes, Crimes Against Peace and Against Humanity), adopted at Berlin, 20 Dec. 1945, Official Gazette of the Control Council for Germany, No. 3, Berlin, 31 Jan. 1946.

8. Draft Statute for an International Griminal Court (Annex to the Report of the Committee on International Criminal Jurisdiction, 31 Aug. 1951), 7 GAOR Supp. 11, U.N. Doc. A/2136 (1952) at 23.

9. Revised Draft Statute for an International Court (Annex to the Report of the Committee on International Criminal Jurisdiction, 20 
Aug. 1953), 9 GAOR Supp. 12, U.N. Doc. A/2645 (1954), at 21.

10. Draft Statute for the Creation of an International Criminal Jurisdiction to Implement the International Convention on the Suppression and Punishment of the Crime of Apartheid, 19 Jan. 1980, U.N. Doc. E/CN.4/1416.

\section{B. UNOFFICIAL TEXTS}

1. Report on the Creation of an International Criminal Jurisdiction, by V.V. Pella to the Interparliamentary Union, XXII Conference, held in Berne and Geneva, 1924, in L'Union Interparliamentaire. Compte Rendu de la XXII Conference tenue a Berne et a Geneva en 1924, public par Le Bureau Interparliamentaire, 1925, see also L'Union Interparliamentaire. Compte rendu de la XXIII Conference tenue a Washington et a Ottowa en 1925 (1925).

2. Projet D'Une Cour Criminelle Internationale, adopted by the International Law Association at its 34th Conference in Vienna, Aug., 1926, The International Law Association, Report of the 34th Conference, Vienna, Aug. 5-11, 1926 (1927).

3. Project of the International Association of Penal Law, in Actes du Premier Congres International de Droit Pénal, Bruxelles, 26-29 June 1926 (1927) and Projet de Statut pour la Creation d'une Chambre Criminelle au Sein de la Cour Permanente de Justice Internationale, presented by the International Association of Penal Law to the League of Nations in 1927, 5 Revue International de Droit PEnal (1928).

4. Constitution et Procedure D'un Tribunal Approprie pur juger de la Responsabilite des Auteurs des Crime de Guerre, presente a la Conference des Preliminaires de Paix par la Commission des Responsabilites des Auteurs de la Guerre et Sanctions, III, La Paix de Versailles (1930).

5. Project for the Establishment of a Convention for the Creation of a United National Tribunal for War Crimes, established by the United Nations War Crimes Commission, 1944, see UNITEd Nations WaR Crimes Commission (Wright ed. 1948).

6. L'Union Interparliamentaire. Compte rendu de la XXVII Conference tenue a Rome en 1948 (1949).

7. Draft Statute for an International Criminal Court, in J. STONE and R. Woetzel, Toward a Feasible International Criminal Court (1970). 
8. Draft Statute for an International Criminal Court, Foundation for the Establishment of an International Criminal Court (Wingspread Conference, September 1971).

9. Draft Statute for an International Criminal Court, Work Paper, Abidjan World Conference on World Peace Through Law, Aug. 26-31, (1973).

10. Draft Statute for an International Commission of Criminal Inquiry and a Draft Statute for an International Criminal Court, International Law Association, 60th Conference, Montreal, Aug. 29-Sept. 4, 1982, in Report of the 60th Conference of the International Law Association (1983).

\section{Instruments on the Codification of Substantive International Criminal Law}

\section{A. OFFICIAL TEXTS}

1. 1954 Draft Code of Offences Against the Peace and Security of Mankind. 9 U.N. GAOR Supp. No. 9, U.N. DOC. A/2693.

2. Draft International Griminal Code, Presented by the AIDP to the 6th U.N. Congress on Crime Prevention and the Treatment of Offenders (Garacas, 1980). U.N. Doc. E/CN.4/NGO 213. Updated in M.C. Bassiouni, A Draft International Griminal Code and Draft Statute for an International. Criminal Tribunal (1987). 


\section{Appendix II}

\section{CHRONOLOGY OF CONTEMPORARY Uं.S. POSITIONS ON THE ESTABLISHMENT OF AN INTERNATIONAL CRIMINAL COURT*}

13 Feb. 1978: Resolution adopted by the House of Delegates of the American Bar Association. It urges the US State Department to open negotiations for a convention for the establishment of an International Criminal Court, with jurisdiction expressly limited to a) hijacking, b) violence aboard aircraft, c) crimes against diplomats and internationally protected persons, and d) murder and kidnapping.

13 Mar. 1986: Statement of Secretary of State George Schultz before the Foreign Operations Subcommittee of the Senate Committee on Appropriations. The agenda is "Foreign Assistance and Related Programs Appropriations for Fiscal Year 1987." Schultz responds to Senator Specter during his testimony that "we need to be working on the web of law that can operate here, and in conjunction with others around the world to say to terrorists that they have no place to hide and they are going to get prosecuted."

25 June 1986: Senator Specter presents Amendment 2187 on the Senate floor and comments on his proposal. The amendment states in part that "rampant terrorism by its very nature threatens world order and thereby all civilized nations and their citizens; any and every nation has the right, under current principles of international law, to assert jurisdiction over offenses considered to be 'universal crimes', such as piracy and slavery, in order to protect sovereign authority, universal values, and the interests of mankind." Specter, in the amendment, also suggests that the President establish an international criminal court that would have jurisdiction over the crime of international terrorism. $\mathrm{He}$ acknowledges that because of issues of sovereignty, various nations might be reluctant to act together on such an initiative. He argues nevertheless that "if these crimes were prosecuted in a world tribunal, there could be no question that such prosecutions ... . would have much greater force and much greater weight than those prosecutions in an individual state." The amendment was agreed to.

- This chronology was prepared by Charles Bataglia, Assistant to United States Senator Arlen Specter. It was slightly edited by the author. 
27 Aug. 1986: Public Law 99-399, the Omnibus Security and Terrorism Act mandates the President to consider "the possibility of eventually establishing an international tribunal for prosecuting terrorists." This Act also includes an amendment (Chapter 113A) to Part I of title 18, United States Code which defines and stipulates penalties for terrorist acts abroad committed against US nationals.

16 June 1988: Testimony of Secretary of State George Schultz before the Foreign Operations Subcommittee of the Senate Committee on Appropriations. The agenda is "Foreign Assistance and Related Programs Appropriations for fiscal Year 1989." Senator Specter asks Secretary Schultz whether it would be "useful" to "push ahead with an international tribunal for the trial of these kinds of international criminals [terrorists]." Secretary Schultz replies that "it may be an important possibility," and notes that "over a period of years now more and more usefulness of the rule of law in getting at terrorism and drug trafficking."

1988: Senator Specter includes a provision in the Omnibus Anti-Drug Abuse Act calling on the President to pursue negotiations to establish an international criminal court with jurisdiction over international drug trafficking.

2 Mar. 1989: House Concurrent Resolution 66, submitted by Congressman Jim Leach of Iowa. The resolution calls for "the creation of an International Criminal Court with jurisdiction over internationally recognized crimes of terrorism, illicit narcotics trafficking, genocide, and torture, as those crimes are defined in various international conventions."

15 Mar. 1989: Floor Statement by Senator Specter on international terrorism. Specter recalls that in a 1986 amendment to the Omnibus Diplomatic Security and Antiterrorist Act and in Section 4108 of the 1988 Omnibus Anti-Drug Abuse Act, Congress called on the President to pursue negotiations to establish an international court with jurisdiction over terrorism and drug trafficking. He goes on to say that his discussions with various foreign leaders have persuaded him that "the civilized international community is prepared to speak with one voice to condemn terrorism." The creation of an international criminal court, he concludes, "would be an eloquent expression of that condemnation."

15 Mar. 1989: Testimony of Secretary of State Baker before the Subcommittee on Foreign Operations of the Committee on Appropriations. Senator Specter asks Secretary Baker what he thinks of the possibility of an international court. Secretary Baker calls the idea "interesting," 
but says it has "some fundamental problems." For instance, there are the questions of who would conduct the investigations, who would bring the prosecutions, and the exact composition of the court. Still, Baker admits "we could probably reach some sort of a United States position on that and then after some period of time, perhaps an international agreement." He concludes that the idea of an international court is worthy of further consideration.

Autumn 1989: The United Nations places the question of establishing an international criminal court for illicit drug traffickers on the Fall agenda of the UN General Assembly.

20 Nov. 1989: UN General Assembly Agenda Item 152 (44th session, Sixth [Legal] Committee). This resolution, following three days of intense debate, requests that the International Law Commission address the possibility of establishing "an international criminal court or other criminal trial mechanism," the jurisdiction of which would include illicit trans-national drug trafficking.

18 June 1990: Floor Statement by Senator Specter. Specter describes a symposium held at his request to discuss the creation of an international criminal court. At the 10 May 1990 symposium chaired by Professor M.C. Bassiouni, 13 international criminal law scholars and government officials joined by Congressmen Bob Kastenmeier and Jim Leach, expressed a consensus that "a regional international criminal court of limited scope and powers had the potential for making a significant contribution in the area of narcotics trafficking and should be further explored." Specter includes in the Congressional Record a copy of the written consensus drafted at the symposium.

24-28 June 1990: The Draft Statute for an International Criminal Tribunal prepared by Professor M.C. Bassiouni and discussed at the May 10 symposium is presented to a special committee of experts organized by the International Institute of Higher Studies in Criminal Sciences. A model draft statute to establish an international criminal tribunal is prepared and in August, 1990 the Committee submits it to the Eighth United Nations Congress on Crime Prevention and the Treatment of Offenders.

16 July 1990: Draft Report of the International Law Commission on the work of its 42nd session in Geneva (1 May - 20 July 1990). In Chapter II, Part $\mathbf{C}$ of this report, the Commission considers, and agrees in principle with, the idea of establishing a permanent international criminal court "to be brought into relationship with the United Nations system." The commission notes that there are at least three possible 
models: 1) an international criminal court with exclusive jurisdiction, 2) concurrent jurisdiction between an international criminal court and national courts, and 3) an international criminal court having only a review competence. Professor S. McCaffery of the U.S. and a member of the ILC supports the report.

7 Aug. 1990: President Cesar Oaviria Trujillo of Colombia, who had planned to attend the Siracusa meeting of June 1990 (but sent three representatives who briefed him on it), vowed in his inaugural address to "explore the possibility of creating an international or regional criminal jurisdiction to fight narco-trafficking and other related crimes that surpass international borders."

4 Sept. 1990: Testimony of Secretary of State Baker before the House Foreign Affairs Committee points out that "defendants of the nature of Saddam Hussein or for that matter Pol Pot" do not answer to any judicial authority, Congressman Leach asks Secretary Baker to look seriously at the idea of creating an international criminal court. Secretary Baker replies that he thinks "the suggestion is a good one" and wonders "why that's not something that had been looked at before, if indeed it hasn't been."

10 Sept. 1990: Testimony of Under Secretary of State Robert Kimmitt before House Foreign Affairs Committee. Kimmitt states that the Leach and Specter proposals would be "enormously complex" undertakings, noting, for instance, that if the State Department wanted to go forward on these proposals, it would have to come to the Senate for advice and consent first. Still, Kimmitt expresses "no disagreement at all" on the mechanism and the principle involved in the Leach proposal. $\mathrm{He}$ adds, in fact, that he would like to bring in lawyers in other agencies and departments who are working right now on the Gulf situation. Kimmitt concludes that "the time is probably riper than ever to look closely at that situation." (international criminal jurisdiction).

11 Sept. 1990: By a vote of 97 to 2, the US Senate endorsed the idea of trying Saddam Hussein before an international tribunal.

19 Sept. 1990: During Congressional Testimony, Congressman Gus Yatron asked John Bolton, Assistant Secretary of State for the Bureau of International Organization Affairs, for his comment on House Concurrent Resolution 66, the House measure promoting the proposed court. Bolton said that the Department of State was open to discussing the merits of the court.

19 Oct. 1990: By unanimous consent, the Senate passes an amendment to the FY 91 Foreign Operations Appropriations bill. The amendment 
calls for the President to report to the Congress by October 1, 1991, the results of his efforts in regard to the establishment of an International Criminal Court to deal with criminal acts defined in international conventions. It also requires the Judicial Conference of the United States to report to the Congress by October 1, 1991 on the feasibility of, and the relationship tō, the Federal Judiciary of an international criminal court.

25 Oct. 1990: In conference on the FY 91 Foreign Operations Appropriations bill, House conferees recede to the Senate's position on the Specter amendment. The bill passes the Congress and is signed into law by the President on

5 Nov. 1990: President Bush signs into Law the FY 91 Foreign Operations Appropriations which includes the Specter amendment.

1990: The U.S. is among the sponsors of the UN General Assembly declaring the nineties as the Decade of International Law. 
